\title{
FOLK SENTIMENT ON VOC AND DUTCH COLONIAL: Syekh Lemah Abang Discourse in Colonial Period of Cirebon
}

\author{
Wakhit Hasim \\ Institut Agama Islam Negeri (IAIN) Syekh Nurjati Cirebon \\ Email: wakhit.hasim2@gmail.com
}

\begin{abstract}
Abstrak
Kontroversi Syekh Lemah Abang dalam manuskrip Cirebon terjadi pada narasi ambigunya. Ambiguitas narasi Syekh Lemah Abang mengacu pada historiografi anakronisme naskah. Berdasarkan ambiguitas narasi dan cerita anakronistik ini, penelitian ini menjawab pertanyaan tentang apa hubungan antara kisah Syekh Lemah Abang pada abad ke-16 dan situasi masyarakat Cirebon pada masa VOC dan masa kolonial Belanda pada abad ke-18, saat naskah diproduksi dan direproduksi. Pertama, sejarah politik masyarakat Cirebon ditutupi oleh dominasi penguasa asing. Hanya di periode Sunan Gunung Jati hingga Panembahan Ratu II saja independensi terjadi di Cirebon. Keresahan perasaan pada situasi tersebut diwujudkan pada narasi dari Syekh Lemah Abang menghadirkan pertentangan antara "negara Islam" yang diwakili oleh Wali Songo, dan "masyarakat menyimpang" diwakili oleh Syekh Lemah Abang, dalam periode kehidupan mereka sendiri, yakni pada abad ke-16. Kedua, kebangkitan narasi Syekh Lemah Abang adalah panggilan untuk kebangkitan masyarakat Cirebon terhadap VOC dan dominasi kolonial Belanda. Syekh Lemah Abang dan Wali Songo, merupakan kekayaan dan warisan masyarakat Cirebon. Kebangkitan ini menjawab keresahan perasaan terhadap dominasi VOC dan kolonial Belanda di ke-18, saat naskah pada Syekh Lemah Abang tertulis dan direproduksi.
\end{abstract}

Kata kunci: anakronisme naskah, VOC, dominasi kolonial Belanda

\begin{abstract}
The controversy of Syekh Lemah Abang in Cirebon manuscripts occurs in his ambiguous narrative. This ambiguity of Syekh Lemah Abang narrative refers to the anachronism of historiography of manuscript. Based on this narrative ambiguity and anachronistic story, this research answer the question of what is relationship between story of Syekh Lemah Abang of 16th century. and the situation of Cirebon people in VOC and Dutch colonial Era in 18th century. the time when the manuscripts on it are produced and reproduced. First, political history of Cirebon society is covered by domination of the foreign ruler. Only in the period of Sunan Gunung Jati until Panembahan Ratu II is an independence occurred in Cirebon. This situation was expressed in the narrative of Syekh Lemah Abang by presenting opposition between "Islamic state" represented by Wali Songo, and "the deviate community" represented by Syekh Lemah Abang 16th century. Second, resurrection of Syekh Lemah Abang narrative is the call for resurgence of Cirebon society against VOC and Dutch colonial domination. Syekh Lemah Abang and Wali Songo, both of them are the riches and heritage of Cirebon society. This resurrection answer the unrest feeling against the domination of VOC and Dutch colonial in 18th, the time when the manuscript on Syekh Lemah Abang written and reproduced.
\end{abstract}

Keywords: anachronism manuscript, VOC, the Dutch colonial domination

\section{A. Introduction}

Syekh Lemah Abang is one of the important complementary stories that exist within the various manuscripts especially on history of Cirebon. ${ }^{1}$ The core theme of manuscripts that

1 Wildan, Dadan, M. Hum. (2003). Sunan Gunung Jati (Antara Fiksi dan Nyata): Pembumian Islam dengan Pendekatan Struktural dan Kultutral. Bandung: are related to Syekh Lemah Abang narrative is the coming of Islam in Cirebon and West Java. The structure is vary, but the most common is starting from the story of Cakrabuana and her sister and Rara Santang which are children of

Humaniora Utama Press, p.229 
Siliwangi, King of Padjajaran, continued with the journey of them to learn Islam in Java Island and Egypt, the story of Sunan Gunung Jati, son of Rara Santang with the Egyptian Prince, and ended by various narrative including Syekh Lemah Abang narrative.

Syekh Lemah Abang is one of the Nine Saint members (Wali Songo), the person dedicating to spreading Islam in the earlier period of Java Islamization in 16th century. Wali Songo is representation of dominant school of Islamic thought that established in Java. They are consist of nine persons, some of them live in east Java, others in central Java and West Java. They are the committee and the Islamic scholar network supporting to the Islamic monarchy from East Java to West Java. Syekh Lemah Abang live in Cirebon West Java and move to east Java to teach people about Islam. In the end of his live, he was sentenced by death penalty because of difference theological believe. Manuscripts describe that he confess himself as Allah, the God. Dewan Wali Songo executed him in 1506 (16th c.), at Masjid Agung Sang Ciptarasa, in front of Pakungwati Pallace (now is Keraton Kasepuhan). ${ }^{2}$

Why does Syekh Lemah Abang be sentenced by death sentence, is described in manuscripts and other books on Cirebon history. Wildan notices that this story started by telling the 'regularly' meeting conducted by Wali Songo, and one of this meeting they are discussing about the essence of Allah, the God. These are existed in (1) Babad Tanah Sunda; (2) Babad Cirebon; and (3) Carita Purwaka Caruban Nagari. ${ }^{3}$

drew this story in more complete way rather than any other manuscripts. ${ }^{4}$ In this meeting, is told that Syekh Lemah Abang debate the theological issue with other member of Wali Songo. The subject of this debate is on the essence and the attribute of Allah. Syekh Lemah Abang emphasized the idea of unity between Allah and human in this issue, while other member of Wali Songo emphasized the distintive deffereces between Allah and human in essence and atribute.

\footnotetext{
2 Sulendraningrat, P.S. 1985. Sejarah Cirebon. Jakarta: PN Balai Pustaka.

This discussion becomes the issue among Wali Songo. Having this debate, Wali Songo call Syekh Lemah Abang to be responsible for his opinion opposing Wali Songo in the essence of God. They prepare the forum and bring Syekh Lemah Abang to it to be judged. This meeting ended unhappily by killing Syekh Lemah Abang. Sunan Kudus is the officeial representation to execute him in front of the Great Mosque or Masjid Agung Cirebon.

The story is not ended here, but still continued with the incredible case. Various stories following the execution of him such as: (1) there are voices of supernatural force saying and worrying people of the coming of "kebo bule mata kucing", interpreted as the colonial government; (2) there is fragrant aroma from the blood of him; (3) the blood spilling the word "kalimah syahadah"; (4) the death body of him transform to the form of beautiful flower. ${ }^{5}$

\section{B. Research Question and Methodology}

The story told that Syekh Lemah Abang was the honorable person because he was a member of Nine Saints. He is also having many followers spreading from West Java until East Java. In spite of criminalizing him by death penalty within the judging process, various sources explaining the incredible story following his death execution. The good and exemplary story recovers him from being told as criminal, but he is still a honorable persons, and Javanese people respect him from his time until now.

There are several problems in this story regarding to history of Cirebon society. First, this process of judging takes Nine Saint in state position because the court is belonging to the state. In contrary, Syekh Lemah Abang as the accused is the enemy of the state, even though state cannot kill his character by executing him.

Second, the story of Syekh Lemah Abang judging is covered by anachronism story. This trial is happen in 16th century in Cirebon, but by looking more detailed to the story, it is found that the process of the judging is not suitable with court system of 16th century but correspond more to 17 th -18 th system of court. $^{6}$

\footnotetext{
5 Sulendraningrat, Op.cit, 1985. Wildan, Op.cit,. 2002.

6 Hoadley, Masson. 1994. Selective Juducial Cometence, The Cirebon Priangan Legal Administration, 1680-1792. New York: South Asia Program, Cornell
} 
From this anachronistic story, this research will answer the question: what is relationship between story of Syekh Lemah Abang of 16th c. and the situation of Cirebon people in VOC and Dutch colonial era in 18th c., the time when the manuscripts on it are produced and reproduced. My hypothesis is that the relationship within the two situations, the situation of Syekh Lemah Abang narrative, and the situation of Cirebon people in 18th century is the unrest situation of Cirebon society and their sentiment to the foreign ruler of Cirebon (VOC) and to the colonizer, the Dutch.

The source of Syekh Lemah Abang narrative is varying, but this paper only based on Cirebon manuscript. This is because the focus of this paper is to understand about sentiment of Cirebon society to the state under VOC and Dutch Colonial that is represented within the manuscripts. The analysis basically employ the historical method, and it is will be enriched by social identity analysis.

\section{Political History of Cirebon: Survive under Foreign Ruler}

Cirebon from 15th century until 20 century in brief is characterized by surviving society from the foreign ruler and colonial government. When Cirebon was established 1445, it is under Padjajaran rule. Padjajaran become the protector of Cirebon, and Cirebon is one of the vassals of Padjajaran. Cakrabuana Prince, son of Siliwangi, King of Padjajaran, hands his position over Sunan Gunung Jati in 1479. Cakrabuana get the inheritance as the successor his father when Siliwangi passed away in 1482. Cakrabuana extended his posisition as the successor of Siliwangi to Sunan Gunung Jati, to power over the rest of Padjajaran region. Sunan Gunung Jati produces the controversial policy in this year to end Padjajaran protectorate and to proclaim independence of Cirebon in 1480. Sunan Gunung Jati have very long life and he passed away in $1578 .^{7}$

This independence status holds out until Panembahan Ratu II period. In 1649, Amangkurat I invite him and his two princes. Amangkurat I take collaboration with VOC,

University

Sulendraningrat, Op.cit,. 1985 and he suspect Cirebon and Banten have plan to rebel him because of it. Anticipating this rebelion, he invites Panembahan Ratu II to visit Mataram with his two princes without giving reason. Panembahan Ratu is forbiden to go bact to Cirebon with his two princes, and they have to live in Mataram. ${ }^{8}$

Pangeran Wangsakerta, the third son of Panembahan Ratu II, tak care of Cirebon palace when his father and his two brother are captured. His after passed away in Mataram in 1667, and his two brothers went back to Cirebon in 1678. Banten monarchy that still have family relationship with Cirebon, help Cirebon in taking back of the two prince. The case of Trunajaya rebellion against Mataram in 1677 is giving a chance to do this (Tim Depdikbud, 1984; Adeng et all., 1998). Brandes describes that Banten motive is not only because of the family relationship with Cirebon in freeing two princes, but because Banten want to use his power to influence Cirebon. Sultan Ageng Tirtayasa of Banten makes an agreement with Trunajaya, they support Trunajaya's movement against Mataram, and Trunajaya support Banten to freeing princes of Cirebon. They have the same enemy that is Mataram and VOC. When Trunijoyo attaches Mataram in 1677, he move the princes to Kediri, and Sultan Ageng Tirtayasa pick them up and taking them back to Banten. ${ }^{9}$

The return of princes of Cirebon from Mataram changes the structure of monarchy. Cirebon palace is divided into four districts or palaces under agreement of Banten and VOC. Sartono Kartodirjo describes that Pakungwati Palace firstly is divided into three palace refers to three princes which claimed have right to succeed their father position. These three palaces are Kasepuhan palace, hold on by Pangeran Mertawijaya, with new title Panembahan Sepuh; Kanoman palace, hold on by Pangeran Kertawijaya, with new title Panembahan Anom; and Kacirebonan palace, hold on by Pangeran Wangsakerta. ${ }^{10}$

Sulendraningrat, who is a prince of Kacirebonan Palace, has different version on this case. He said this division occurred in 1677, and

Buchari \& Kuswiyah, 2001.

Adeng et all., 1998.

Buchari \& Kuswiyah, 2001. 
Pakungwati palace is divided into two palaces, Kasepuhan palace with Mertawijaya prince as Sultan Sepuh entitled Sultan Raja Samsudin; and Kanoman palace with Kartawijaya prince as Sultan Anom entitled Sultan Muhammad Badriddin. Pangeran Wangsakerta is not having the authority in special palace; he became the assistant of Sultan Sepuh, entitled Panembahan Toh Pati. VOC creates friendship agreement signed by two princes in 1681, Cirebon Palaces grew weaker and weaker until VOC totally control over the Cirebon in $1700 .^{11}$

Having weak development because of VOC's intervention, two sons of Sultan Anom move to disobeyed VOC in silence, by creating a district for Pangguron Islam Prabonan/Prabonan Islamic School area called Keprabonan. This area token from Kanoman district is hold on by second prince entitled Rama Guru Pangeran Raja Adipati Keprabonan. Kacirebonan is the rest division in Kanoman Palaces after establishing Keprabonan. It is established in Sultan Anom Mumammad Khaeruddin (IX) for one of his son entitled Sultan Carbon. Sultan title is forbidden for him by VOC, and his descendent only can use the title Pangeran Raja Madenda Kepala Keluarga Kacerbonan. ${ }^{12}$

VOC take advantages from this situation. VOC make some agreement with Amangkurat I including the position of Cirebon. PJ. Veth describes that Cirebon King is politically under Mataram Kingdom, king of Cirebon token as the religious leader un sich in 1662. Cirebon sign an agreement under the force of VOC in 1681, that Cirebon is under protectorate of VOC. In the same time, Mataram still consider Cirebon as their vassal. Cirebon in rest period never controls their own sovereignty. The status of Cirebon becomes the subject area to control by Banten, VOC and Mataram. (Tim Depdikbud, 1984). With principle of "devide at impera", control gradually over the status of Cirebon from 1681, and effectively from 1688-1799. And from 1788 - 1942 Dutch colonial take absolutely the rule of Cirebon Monarchy. ${ }^{13}$

\begin{tabular}{|c|c|}
\hline PERIODE & POLITICAL EVENT \\
\hline $1445-1480$ & $\begin{array}{l}\text { Opening the village. Era of Kuwu Sangkan } \\
\text { (First head of village) \& Cakrabuana } \\
(\text { Kuwu II) }\end{array}$ \\
\hline $1480-1620$ & $\begin{array}{l}\text { Independent era of Cirebon, from Sunan } \\
\text { Gunung Jati to Panembahan Ratu II. }\end{array}$ \\
\hline $1620-1681$ & $\begin{array}{l}\text { Cirebon under Mataram protectorate and } \\
\text { Banten } \\
\text { Luwangan Mataram, Undang-Undang } \\
\text { Luwangan Mataram } \\
\text { (before } 1677 \text {, Priangan use this Javanese } \\
\text { System of court) } \\
\text { Cirebon Divided into two Sultanates } \\
\text { (Kasepuhan and Kanoman), and then } \\
\text { Kanoman divided into three are (Kanoman, } \\
\text { Keprabonan and Kacirebonan). } \\
1681 \text { VOC offered collaboration contract } \\
\text { with Cirebon, and start to penetrate } \\
\text { Cirebon policy }\end{array}$ \\
\hline $1681-1799$ & $\begin{array}{l}\text { VOC administration } \\
1700 \text {, Yacob Palm become a residence, and } \\
\text { he take the policy in absolute power over } \\
\text { Cirebon } \\
\text { Layang Ubaya, 1681, Company (VOC) } \\
\text { sign the contract with Cirebon authority, } \\
\text { legalized in 1688, still use Javanese legal } \\
\text { form, (Padu and Pradata System) } \\
\text { (Lately in 1768, VOC proposed Pepakem } \\
\text { Cirebon, legally binding for a 11 of } \\
\text { monarchy in Cirebon in one stop office). } \\
\text { Javanese Court System (before } 1677 \text {, } \\
\text { Luwangan), used in Cirebon, adopted with } \\
\text { the new one (1685/88, Layang), totally } \\
\text { controlled by Dutch colonial at } 1768 \\
\text { (Pepakem Cirebon) }\end{array}$ \\
\hline $1800-1942$ & Dutch Colonial era \\
\hline
\end{tabular}

From this brief chronicle, Cirebon have the real independence only from 1480-1620. From 1445-1480 Cirebon relatively have freedom to established town, military, port, and legal system under monarchy of Padjajaran. Padjajaran supports Cirebon by establishing infrastructure for the main building of government, now the ruin available in Gunungjati district, and platoon of army for security force. For the substitution, Cirebon have obligation to pay the annual tax to Padjajaran. Sunan Gunungjati takes a big decision when he declare the independence of Cirebon from Padjajaran after that. This status is hold out until Panambahan Ratu II period. The rest period, Cirebon lost gradually its supremacy, and totally lost when VOC restructure the rule that take over Sultan supremacy and take Sultan only as an executive agency of VOC in 1768.

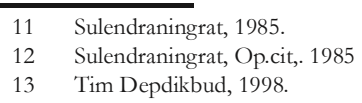


This situation demand strategies for Cirebon Monarchy to survive under foreign ruler. The strategy that occur within overall historical narrative are:

1. Maintenance the relationship with neighbor to service, particularly with Banten, Mataram and even VOC. From this maintenance, Cirebon gets the safety and peacefulness relatively. Cirebon did not confront the enemy directly, but indirectly opposed it through collaboration with other force. For example, when Panembahan Ratu II (Girilaya) opposed Mataram because of Mataram making collaboration with VOC, he collaborates with Banten (Sultan Ageng Tirtayasa) to support Trunajaya secretly. It's happen to in dividing process of Cirebon monarchy. Banten try to infiltrate Cirebon monarchy by helping two princes from Mataram capture, and lead those to divide Cirebon monarchy into three small palaces, Cirebon ask VOC to help this process.

2. Disobeying the rule of the oppressor. This is like what happen when Pengguron Keprabonan is build, it is done silence without permission of VOC, which is already controlled Cirebon. The Pangguron is the Islamic school based in palace tradition to conserve the values of palace and Islam.

3. Producing subversive narrative. It's kind of weapon of the weak spreading in cultural expression of Cirebon society. One of the products is the narrative of Syekh Lemah Abang in the manuscripts, the expression representing folk sentiment on colonialism.

\section{Folk Sentiment on Colonialism}

The folk sentiment on colonialism here refers to two phenomena: producing manuscripts and creating the plot of Syekh Lemah Abang Narrative. The production of manuscripts telling Syekh Lemah Abang in VOC and the Dutch Colonial era influenced by unrest feeling of upper class society. And the plot of Syekh Lemah Abang colored by anachronism narrative and the ambiguity of the narrative; killing the Syekh Lemah Abang character in one hand, and glorifying his character in other hand. The anachronism narrative with the ambiguity plot is can be understood as the connectivity of two era, the era of Syekh Lemah Abang in 16th century, and the era of VOC and the Dutch Colonial situation. The connection is occurring the unrest feeling of the people under the foreign ruler.

\section{E. Unrest Feeling in Producing the Manuscripts in VOC and the Dutch Colonial Period}

Having life under foreign's ruler influences unrest feeling of Cirebon people. This unrest feeling is represented in Syekh Lemah Abang case, which is in manuscripts produced by upper class society. Here the explanation of: (1) what is social hierarchy of Cirebon which manuscript is produced in, and (2) which one is product of the manuscripts in colonial period.

\section{Social Structure of Cirebon in Colonial \\ Period}

Cirebon society is a hierarchical society; consist of upper class, middle class and lower class. Upper class society consists of elite bureaucrat and religion, such as the King and family, palace officials and elite religious leader. Influenced by Hinduism tradition, King and family have a imitate relationship with common people; live in at the palace with the wall as the boundary. They do not go out to the people unless they have some task to do. Middle class consist of middle level palace official, religion leader and syahbandaror/harbour master. For Syahbandar, this position needs high skill communication and has international networking with countries in the world. For this reason, the position is not always hold by indigenouse people, some time hold by Dutch people in Cirebon, and Chinese and Gujarat in Banten. The low class society consists of low worker, fisher, farmer, and seller. They are in position like supporting system for the whole society. People depend on them in providing foot, work, and other daily skill and need. ${ }^{14}$

The upper class tradition is the more subject of the history of Cirebon. After the death of Sunan Gunungjati, they fall in weak 
position. Atja describes that Mataram infiltrate Cirebon from 1615 and in 1960 Cirebon as a whole is the vassal of Mataram. The worst is that there was news that Cirebon is no longer become a political unity in 1684 , it is totally just as the province of Mataram. ${ }^{15}$

Banten, VOC and Mataram, as mentioned above, they compete each other to dominate Cirebon. Some time they collaborrate one another, and in other time they challenge each other. In this situation, VOC have a good change to control Cirebon, by his famous adagium "devide et impera" or "divide and role. In the 18th century, the Dutch totally controlled Cirebon society. Cirebon have no more power over the politic and economy.

\section{Producing Manuscripts in Colonial \\ Period}

Suffer from losing independency, Cirebon monarchy lose control over their political sovereignty and economy. In other hand, they have large time to doing cultural and spiritual activities for example art and literature. Untung Raharja notices that in colonial period, the life style of upper class society related with the demand of this condition. For example, to conserve the dignity of ancestors and their charisma, Sultans of Cirebon used to create things such as maintaining the titles, like prince and sultan; formulating the genealogy of family, from Adam until the Cirebon officials; developing palace's culture; collecting heirloom; and conserving the legend and socializing it to the people, particularly that related with the supernatural force of them. ${ }^{16}$

Manuscript on Cirebon history like babad, is one of the way to presenting this unrest feeling. How to understand about manuscript orientation, we can find out from who is the author. Dadan Wildan describes that the author coming from palace writes manuscripts commonly to legitimate power and position, and the author coming from pesantren or Islamic boarding school writes usually on Islamic preaching. ${ }^{17}$

These manuscripts coming from this period are various, some of that are Carita Pustaka

\footnotetext{
15 Adeng et all., 1998

16 Raharja, 2005.

17 Raharja, 2005. p. 49.
}

Caruban Nagari, a work of Pangeran Arya Cirebon, writen in 1720, Pepakem Jaksa Pepitu, 1765, Pustaka Pakungwati, collaborative work of Ki Wangsa Manggala (Cirebon Demang), Ki Jakani (Islamik Clerick/Penghulu) andKi Mitsal, writen in 1779, Babad Raatu Carbon Girang, Ki Somad Manggala, 1790, Wewacan Cerbon, Ki Demang Pamayahan, 1805, Catur Kanda, Pangeran Arya Suraadiningrat, 1848, and Babad Galuh, Kyai Surengrana, 1876. ${ }^{18}$

The case of Syekh Lemah Abang used to come from manuscripts coming from this period to the letter periode. The manuscripts telling Syekh Lemah Abang case are many, but some of these are bellow:

a. Pustaka Negara Kertabhumi (PNK), written by Wangsakerta Prince, in 1698, reproduced in $18 \mathrm{c}$, edited and published by Ekajati et.all (1991).

b. Carita Purwaka Caruban Nagari (CPCN), written by Arya Cirebon Prince, in 1720, edited and published by Atja et all (1986).

c. Serat Catur Kanda, written by Aria Suradiningrat, in 1848, publishe by Tim Keraton Kasepuhan, 2003.

d. Sejarab Cirebon: Naskah Keratorn Kacirebonan, written by ... In 1860, (putra Sultan Sepuh Syamsudin era), published by Irianto, Drh. H. R. Bambang, BA \& Sutaraharja, Ki Tarka. (2013).

e. Babad Tanab Sunda, translated by Sulendraningrat, published in 1982.

f. Babad Cirebon, Carub Kanda, Naskah Tangkil., written by Ki Kampah, published by Irianto et all., 2013.

g. Carub Kanda: Carang Seket, published by Z.H., Sudibjo \& Sudjana,T.D. (1980).

b. Koleksi Naskah Kuno Keraton Kasepuban Cirebon, published by Tim Keraton Kasepuhan Cirebon. (2003).

i. Wawacan Sunan Gunung Jati, edited bu Emon S.A. et all, published in 1994.

j. Sejarah Cirebon, written by Sulendraningrat, 1985.

k. Kisah Masyarakat Cirebon (Oral Tradition), published by Wildan, 2002.

From this list, there are four manuscripts that the writing time is mentioned clearly in the manuscripts. But other manuscripts are without

18 Raharja, 2005. 
writing time explanation. I assume that these manuscript are written in the same period, or writes later in 19th or or 20th century, because its characteristic is refer to Islamic culture of Cirebon, or the recent work but refer the source to the manuscripts in this period, for example the book History of Cirebon by PS Sulendraningrat, written in 1985, the reference refers to the work of Pangeran Aria Cirebon, 1698.

\section{F. The Plot of Syekh Lemah Abang Narrative}

Anachronism and ambiguity of Syekh Lemah Abang narrative are the characteristic of the manuscripts regarding folk sentiment on VOC and the Dutch colonial ruler. The anachronism occurred in the way the manuscript describe the judging process, and the ambiguity occurred in the way the narratives describes the character of Syekh Lemah Abang as a deviant and as an saint in the same time.

\section{The Court System in Syekh Lemah Abang Judging Process}

The trial of Syekh Lemah Abang occurring in 16th century is correspond to and based on pradata court system. The competence of this court is belong to the King, consist of criminality against people, particularly against the crown. ${ }^{19}$ The manuscript describes this case in various ways. According to Nagara Kretabhumi manuscripts, writen by Pangeran Wangsakerta, this case is regarding the rebellion case. Babad Tanah Sunda and Babad Cirebon (Brandes version) does not mentioned the case directly, but describes the process of execution. The execution of Syekh Lemah Abang is done by sticking Keris Kantanaga (wavy double-bloody dagger) own by Sunan Gunung Jati (authority/ king). The rest sources clearly put the court process without involving Sunan Gunung Jati. In Sejarah Cirebon by Sulendraningrat, the judge is Sunan Kalijaga.

The pradata court process is conducted by Sultan/King/supreme authority and lead by him. The problem of Syekh Lemah Abang judging process is not refer to pradata procedures. In contrary, this judging, even

19 Hoadley, Op.cit,. 1994. though as the pradata competence, is not with padu court procedure. Competence of padu case is private case between two parties of citizens, and the procedure is formally sitting conducted by judge.

It is refer to the changing procedure of the court in 18th century. In 18th century, there is particular official replace and on behalf of King position in court. By this new system, the King is absent from the pradata court judging process, and replaced by the court official, unless the case cannot be solved by the official. This new system of court effectively done in 18th century when Cirebon established the united system among four Keraton which are Kasepuhan, Kanoman, Keprabonan and Kacirebonan, under Pepakem Cirebon, initiated by VOC. ${ }^{20}$

From this discussion, we find that all of the session of judging not involving the supreme authority must be the projection of 18th court system practice. The problem is, why the narrator reformulates this case from 16 th century court system into the 18 th century court system? It is probably reasonable since the manuscripts is written in 18th century, and the reader manuscripts address for is the reader of 18th century. The procedure of judging of 16th century for Syekh Lemah Abang case is reformulated with the 18th system of court. But the most strong reason is referring to the unrest situation of both 16th and 18th century influencing the the sentiment of Cirebon people to the colonialism.

\section{The Ambiguity of Syekh Lemah \\ Abang Narrative}

The unrest situation of both 16th and 18th century influencing the the sentiment of Cirebon people to the colonialism is occurred in the ambiguity of Syekh Lemah Abang narrative. The structure of the narrative ${ }^{21}$ is bellow:

a. There is regularly meeting conducted by Wali Songo, and one of this meeting they are discussing about the essence and the attribute of Allah, the God (Babad Tanah Sunda; Babad Cirebon; and Carita Purwaka Caruban Nagari).

b. Syekh Lemah Abang emphasized the idea of sameness and unity between Allah and

20 Hoadley,Op.cit,. 1994.

21 Wildan, Op.cit,. 2002., dan Sulendraningrat, Op.cit,. 1985. 
human in this issue, while other member of Wali Songo emphasized the distinctive differences between Allah and human in essence and attribute.

c. Other member of Wali Songo does not like Syekh Lemah Abang opinion, and think that his thought is dangerous. Because of this reason, Wali Songo call Syekh Lemah Abang to be responsible for his opinion in forum conducted by them.

d. This meeting ended unhappily by killing Syekh Lemah Abang. Sunan Kudus is the official representation to execute him in front of the Great Mosque or Masjid Agung Cirebon.

e. The incredible stories following the execution of Syekh Lemah Abang such as: (1) there are voices of supernatural force saying and worrying people of the coming of "kebo bule mata kucing", interpreted as the colonial government; (2) there is fragrant aroma from the blood of him; (3) the blood spilling the word "kalimah syahadah"; (d) the death body of him transform to the form of beautiful flower. From the number $1-4$, the narrative is clearly understood that Wali Songo is in the right side and Syekh Lemah Abang is in the wrong side. Wali Songo defends the majority understanding of God as the holy essence with holy attribute. It is must be difference with the essence and the attribute of human kind. God has to be purified and sterile from human characteristic (tanzib). The holy of God will be soiled by the idea of sameness (tasybih) and unity between God and human.

Defending the puricification of God, Wali Songo represented the State position toward the people. Wali Songo are the ulama who support to the establishment of the new Islamic Kingdom in Java at 16th century. State interest is the social order. The best legitimation is religion thought, particularly theology.

It is clear in Negara Kretabhumi manuscript that the position of Syekh Lemah Abang politically is against Wali Songo. Syekh Lemah Abang try to build new system of society based on Syi'ite theology against Hanafi's tradition in Demak, Central Java, and Syafi'is tradition in Cirebon, West Java. He failed in moving people in Cirebon, and Sunan Gunung Jati asks him to go out from Cirebon because of this case. He move to Demak, and meet with Kebo Kenongo, the leader of Pengging district. Through Ki Ageng Pengging or Kebo Kenongo, Syekh Lemah Abang implements his vision in establishing Syi'ite base social system in Pengging, one of the distric of Demak, which is opposing to Demak Kingdom. Wali Songo is the party who establish Demak. Negara Kretabhumi counted this movement as the rebellion against the Islamic state, Demak.

Manuscripts take the opposite position between Wali Songo and Syekh Lemah Abang in this narrative. The narrative representing position of social agency as this:

Self : Wali Songo/Demak Sultanate/right side/new Islamic Kingdom/new society Other: Syekh Lemah Abang/Pengging/wrong side/cult community/deviant society Manuscript in this narrative represented the 16th century situation, when the new Islamic kingdom need a unity of society, and need the uniformity of the religion belief. It is occur in Demak, Central Java, as well as in Cirebon, West Java.

This opposing position is broken in the narrative no. 5. This theological issue and political case addressing to Syekh Lemah Abang does not kill his character. In contrary, this narrative support to the existence of Syekh Lemah Abang. Syekh Lemah Abang is not in the wrong side. Syekh Lemah Abang still one of the Saint who love people, and who is respected by people.

Syekh Lemah Abang's resurrection is speaking loud of the situation in 18th century. The coming of VOC's infiltration and the eshtablishment of the Dutch colonial take over Cirebon sovereignty. Cirebon is no longer the strong state as in 16th-17th century, which was independent from foreign rulers. Cirebon in 18the century did not have any sovereignty unless the symbol of culture, the ruin of the old kingdom. Cirebon have no sovereignty in economy and politic.

In this case, the entire cultural heritage of Cirebon is valuable to be resurrected. Nine Saint, or Wali Songo, is became the gift from 
the past, the valuable historical narrative, that own by Cirebon society. Cirebon is the town of Saint. But Cirebon not only have the nine Saint, Cirebon have Syekh Lemah Abang, which was very legendary person, honorable, and leave various narrative embodied in Cirebon society. He is the great person who have the many follower. All of this wealth is important to be affirmed. It is important for building the character of Cirebon society against the VOC and the Dutch, the infidel force that infiltrated Cirebon society.

The narrative no. 5 is the 18 th characteristic, written with the 18th century court system, and correspond to the unrest situation against VOC and the Dutch colonial. The structure of the narrative can be described as bellow:

\section{Self : Wali Songo \& Syekh Lemah Abang/ Cirebon kingdom/Islamic heritage}

Other: VOC \& Dutch/foreign ruler/infidel force

This position in one hand is the ambiguity of Syekh Lemah Abang narrative; in other hand is the creativity of Cirebon society in conserving their values, and in maintaining their identity against the colonialism.

\section{G. Conclussion}

The controversy of Syekh Lemah Abang in Cirebon manuscripts occur in his ambiguous narrative. In one hand, his position as one of Wali Songo member is damaged by his new status as defendant in criminal court. Wali Songo take him to the court because Syekh Siti Jenar brings the idea of unity of God and human which Wali Songo put it as the deviate from Islamic theology. In other hand, Syekh Siti Jenar character is still live and resurrect with the incredible story following his death execution. The good and exemplary story recovers him from being told as criminal, even he is known as a honorable persons, and Javanese people respect him from his time until now. This ambiguity of Syekh Lemah Abang narrative refers to the anachronism historiography of manuscript, particularly with respect to the court system which Syekh Lemah Abang case was being judged. The 16th century court system when the case is occuring is absent and the 18th century court system replaced it in judging Syekh Lemah Abang case.

Based on this narrative ambiguity and anachronistic story, this research answer the question of what is relationship between story of Syekh Lemah Abang of 16th c. and the situation of Cirebon people in VOC and Dutch colonial Era in 18th c., the time when the manuscripts on it are produced and reproduced. My thesis to answer this question is that the relationship within the two situations, the situation of Syekh Lemah Abang narrative, and the situation of Cirebon people in 18th century is the unrest situation of Cirebon society and their sentiment to the foreign ruler of Cirebon (VOC) and to the colonizer, the Dutch for two reason. First, political history of Cirebon society is covered by domination of the foreign ruler. Only in the period of Sunan Gunung Jati until Panembahan Ratu II is the independent occurred in Cirebon. The most unrest feeling of Cirebon society is coming when VOC inviltrate the economic sovereignty in 17th-18th century, and when the Dutch colonial take role over in 18th -20 th century, Cirebon lost their political and economical sovereignty. This unrest feeling embodied within the narrative of Syekh Lemah Abang by presenting opposition between "Islamic state" represented by Wali Songo, and "the deviate community" represented by Syekh Lemah Abang, in their own life period, 16th century.

Second, resurrection of Syekh Lemah Abang narrative is the call for resurgence of Cirebon society against VOC and Dutch colonial domination. Cirebon as a whole is multicultural, and the multicultural is the strength of Cirebon society. Syekh Lemah Abang and Wali Songo, both of them are the riches and heritage of Cirebon society. This resurrection unswer the unrest feeling against the domination of VOC and Dutch colonial in 18th, the time when the manuscript on Syekh Lemah Abang written and reproduced. 


\section{References}

Irianto, Drh. H. R. Bambang, BA \& Sutaraharja, Ki Tarka. (2013). Sejarah Cirebon: Naskah Keratorn Kacirebonan, Alib Aksara dan Bahasa Teks KCR 04. Yogyakarta: Deepublish.

Kampah, Ki. (2013). Babad Cirebon, Carub Kanda, Naskah Tangkil. Yogyakarta: Deepublish.

Z.H., Sudibjo \& Sudjana,T.D. (1980). Carub Kanda: Carang Seket. Jakarta: Proyek Penerbitan Buku Sastra Indonesia dan Daerah.

Tim Keraton Kasepuhan Cirebon. (2003). Koleksi Naskab Kuno Keraton Kasepuba Cirebon. Jakarta: Perpustakaan Nasional RI.

Ekajati, Edi S., Wartini, Entin, \& A. Darsa,Undang. (1991). Pustaka Negarakretabumi, Parwa I, Sargah 3. Jakarta: Yayasan Pembangunan Jawa Barat.

Tim Kraton Kasepuhan. (2003). Serat Catur Kanda: Punika Wacan Sujarah Kagungan dalem Bupati Cirebon, Rabaden Adipati Hariya Suraadiningrat. Jakarta: Proyek Pembinaan dan Pengembangan Perpustakaan Nasional
Wildan, Dadan, M. Hum. (1981). Sunan Gunung Jati (Antara Fiksi dan Nyata): Pembumian Islam dengan Pendekatan Struktural dan Kultutra. Bandung: Humaniora Utama Press, 2002

Sulendraningrat, P.S. (1985). Sejarah Cirebon. Jakarta: PN Balai Pustaka.

Hoadley, masson. (1994). Selective Juducial Cometence, The Cirebon - Priangan Legal Administration, 1680-1792. New York: South Asia Program, Cornell University.

Aripin, Dr. Jaenal H., M. Ag, (et all.) (2012). 130 Tahun Peradilan Agama; Dari Serambi masjid ke serambi dunia. Jakarta: Direktort Jenderal Badan Peradilan Agama, Mahkamah Agung RI.

Kern, R. A. \& Djajadiningrat, Hoesein. 1974. Masa Awal Kerajaan Cirebon. Jakarta: Bhratara. Gatra No. 5 - 6, Tahun VIII, 2001

Wahid, Abdul. 2014. Dutch Colonialism and Religion in Indonesia. Yogyakarta: ICRS UGM, slide presetation papers for the the history of Religion in Indonesia Course, copied only for the student. 